\title{
PENGARUH PENGELUARAN PEMERINTAH BIDANG PENDIDIKAN DAN KESEHATAN TERHADAP INDEKS PEMBANGUNAN MANUSIA DI INDONESIA
}

\author{
Jehuda Jean Sanny Mongan \\ Universitas Gadjah Mada \\ Alamat Korespondensi: kido.180188@gmail.com
}

\begin{abstract}
Recently, development paradigm is shifting from being initially centered on economic growth to human-centered development. Human development has become an indicator for the progress of a country. HDI is an indicator used to measure the quality of human life, and can be used to determine the ranking or level of development of a region. Indonesian government consider human-centered development as greater importance than other matters. The Government prioritizes the education budget of at least 20\% from APBN and APBD total budget, and as for the health budget is at least 5\% of APBN total budget and $10 \%$ of APBD total budget.

This study aims to analyze how the government expenditure in education and health sector affect the HDI in Indonesia. This study uses panel data regression consist of 32 provinces over a seven years period of 2000-2016. The results of this study indicate that the expenditure central government expenditure in education doesn't have significant effect on HDI. Expenditure of the central government in health sector and expenditure of the local government in education gives positive and significant effect on HDI, while the expenditure of the local government in health sector has a negative and significant effect.
\end{abstract}

\section{KATA KUNCI:}

IPM, Belanja Pemerintah Pusat, Belanja Pemerintah Daerah, Belanja Pendidikan, Belanja Pemerintah Daerah.

\begin{abstract}
ABSTRAK
Paradigma pembangunan telah bergeser dari awalnya berpusat pada pertumbuhan ekonomi ke pembangunan yang berpusat pada manusia. Pembangunan manusia telah menjadi indikator bagi kemajuan suatu negara. IPM adalah indikator yang digunakan untuk mengukur kualitas kehidupan manusia, dan dapat digunakan untuk menentukan peringkat atau tingkat pengembangan suatu wilayah. Pemerintah Indonesia menganggap pembangunan yang berpusat pada manusia lebih penting daripada hal-hal lain. Pemerintah memprioritaskan anggaran pendidikan paling sedikit 20\% dari APBN dan APBD total anggaran, dan untuk anggaran kesehatan setidaknya 5\% dari total anggaran APBN dan 10\% dari total anggaran APBD. Penelitian ini bertujuan untuk menganalisis bagaimana pengeluaran pemerintah dalam pendidikan dan sektor kesehatan mempengaruhi IPM di Indonesia. Penelitian ini menggunakan regresi data panel yang terdiri dari 32 provinsi selama periode tujuh tahun 2000-2016. Hasil penelitian menunjukkan bahwa pengeluaran belanja pemerintah pusat dalam pendidikan tidak berpengaruh signifikan terhadap IPM. Pengeluaran pemerintah pusat dalam sektor kesehatan dan pengeluaran pemerintah daerah dalam pendidikan memberikan pengaruh positif dan signifikan terhadap IPM, sementara pengeluaran pemerintah daerah di sektor kesehatan memiliki efek negatif dan signifikan.
\end{abstract}

\section{KLASIFIKASI JEL:}

H53

\section{CARA MENGUTIP:}

Mongan, J. J. S. (2019). Pengaruh pengeluaran pemerintah bidang pendidikan dan kesehatan terhadap indeks pembangunan manusia di Indonesia. Indonesian Treasury Review, 4(2), 163-176. 


\section{PENDAHULUAN}

\subsection{Latar Belakang}

Pembangunan ekonomi pada hakekatnya merupakan suatu rangkaian kegiatan yang dilaksanakan secara sadar dan terus menerus untuk mewujudkan keadaan yang lebih baik secara bersama-sama dan berkesinambungan. Pembangunan harus dipahami sebagai suatu proses multidimensi yang melibatkan reorganisasi dan reorientasi dari seluruh sistem sosial dan ekonomi yang ada (Todaro \& Smith, 2011). Pembangunan ekonomi pada awalnya memandang keberhasilan pembangunan suatu wilayah dengan ukuran tingginya pertumbuhan ekonomi, tanpa melihat aspek-aspek lainnya, seperti ketimpangan pendapatan, tingkat kemiskinan dan lain sebagainya. Sumber daya manusia hanya dipandang sebagai input dalam proses produksi, seperti halnya faktor produksi lainnya yaitu tanah, modal, dan teknologi.

Nanga (2000) mencermati bahwa setidaknya terdapat tiga kali pergeseran dalam paradigma pembangunan ekonomi. Pertama, paradigma pembangunan yang berorientasi pada pertumbuhan. Paradigma ini menganggap bahwa Produk Nasional Bruto atau Produk Domestik Bruto merupakan indikator tunggal terbaik keberhasilan pembangunan. Sementara persoalan lain seperti kemiskinan, pengangguran, dan ketimpangan pendapatan dianggap sebagai persoalan yang bersifat sekunder. Paradigma ini berkembang pada tahun 1950an dan 1960an. Kedua, pardigma pembangunan yang berorientasi pada pemerataan. Dalam paradigma ini, pemerataan pendapatan dan pengurangan kemiskinan dijadikan sasaran utama dan sekaligus menjadi bagian yang tak terpisahkan dari strategi atau kebijakan pembangunan yang dijalankan. Paradigma ini kemudian mendapat kritik tajam karena cenderung memandang manusia sekedar sebagai objek assistentialism strategy dan charity strategy. Ketiga, paradigma pembangunan yang berpusat pada manusia. Dalam paradigma ini, tujuan dari pembangunan diarahkan pada perkembangan manusia dalam arti aktualisasi nilai-nilai atau potensi-potensi kemanusiaan seperti harga diri (self-esteem), kemandirian (self-reliance), martabat (dignity), pemberdayaan (empowerment), dan sebagainya.

Pada tahun 1990 gagasan pengukuran pembangunan manusia dikembangkan oleh UNDP dalam bentuk Human Development Index (HDI)/Indeks Pembangunan Manusia (IPM) dan dipublikasikan secara berkala dalam laporan tahunan Human Development Report (HDR). IPM memberikan suatu ukuran gabungan tiga dimensi tentang pembangunan manusia yang meliputi kesehatan (diukur dari angka harapan hidup sejak waktu lahir/life expectancy at birth), pendidikan (diukur dari angka melek huruf penduduk dewasa/adult literacy rate dan rata-rata lama sekolah penduduk dewasa/mean years schooling) serta standar hidup layak (diukur dari kemampuan daya beli/purchasing power parity).

Indeks pembangunan manusia kemudian menjadi salah satu indikator yang penting dalam melihat sisi lain dari pembangunan. Manfaat pentingnya IPM antara lain adalah IPM merupakan indikator penting dalam mengukur keberhasilan dalam upaya membangun kualitas hidup manusia (masyarakat/penduduk) serta IPM dapat menentukan peringkat atau tingkat pembangunan suatu wilayah/negara (BPS, 2015).

Pembangunan sumber daya manusia sudah dipandang penting oleh pemerintah Indonesia. Melalui tujuan negara yang teradapat pada alinea ke empat UUD 1945, pemerintah mengemban tugas untuk melindungi segenap bangsa Indonesia dan seluruh tumpah darah Indonesia, untuk memajukan kesejahteraan umum, mencerdaskan kehidupan bangsa, dan ikut melaksanakan ketertiban dunia yang berdasarkan kemerdekaan, perdamaian abadi dan keadilan sosial. Menurut Ritonga (2014), untuk mencapai tujuan negara, pemerintah daerah melaksanakan program dan kegiatan untuk melayani masyarakat di semua bidang pelayanan publik, seperti kesehatan, infrastruktur, pendidikan dan lain sebagainya. Komitmen pemerintah dalam membangun kualitas atau kesejahteraan masyarakat dapat terlihat melalui alokasi pengeluaran pemerintah dari tiga jenis belanja yaitu belanja pendidikan, belanja kesehatan, dan belanja infrastruktur. Berdasarkan indikator-indikator yang menjadi landasan pengukuran IPM, maka bidang pendidikan dan bidang kesehatan memiliki peran penting untuk menciptakan sumber daya dan pembangunan manusia. Dengan demikian sekurangnya ada dua bidang yang perlu diperhatikan oleh pemerintah sehubungan dengan upaya memperluas kesempatan penduduknya untuk mencapai hidup layak yaitu bidang pendidikan dan bidang kesehatan. Dalam hal ini, pemerintah dapat mewujudkan peningkatan tingkat kesejahteraan masyarakatnya melalui peran alokasi belanja pemerintah di bidang pendidikan dan bidang kesehatan.

Menurut Mangkoesoebroto (2016), pengeluaran pemerintah mencerminkan kebijakan pemerintah. Pemerintah yang menetapkan suatu kebijakan tertentu memiliki konsekuensi biaya yang harus dikeluarkan. Biaya tersebut didanai dari anggaran pemerintah yang menjadi pengeluaran bagi pemerintah. Anggaran yang dialokasikan untuk suatu bidang menunjukkan komitmen pemerintah terhadap permasalahan pada bidang tersebut. Sebagai bentuk kebijakan fiskal pemerintah, setiap tahun pemerintah pusat menetapkan UndangUndang Anggaran Pendapatan dan Belanja Negara 
(UU-APBN) sebagai hak dan komitmen pemerintah dalam pelaksanaan pembangunan. Sementara pemerintah daerah setiap tahun menetapkan Peraturan Daerah Anggaran Pendapatan dan Belanja Daerah (APBD) sesuai dengan kebijakan pembangunan masing-masing daerah. Hal ini sesuai dengan semangat otonomi daerah yang mulai berlaku sejak diterbitkannya UU nomor 22 tahun 1999 tentang Pemerintahan Daerah. APBN dan APBD menjadi alat utama pemerintah untuk meningkatkan kesejahteraan masyarakat.

Komitmen keseriusan pemerintah terhadap pembangunan manusia terutama di bidang pendidikan dan bidang kesehatan kemudian dituangkan dalam bentuk suatu peraturan perundang-undangan. Pasal 31 ayat (4) UUD 1945 yang diamandemen pada tahun 2009, mengamanatkan bahwa negara memprioritaskan anggaran pendidikan sekurang-kurangnya dua puluh persen dari APBN dan APBD untuk memenuhi kebutuhan penyelenggaraan pendidikan nasional. Pengalokasian dana pendidikan tersebut kemudian dijabarkan lebih lanjut dalam UU nomor 20 tahun 2003 tentang Sistem Pendidikan Nasional pasal 49. Sementara untuk bidang kesehatan, UU No. 36 Tahun 2009 tentang Kesehatan pasal 171 mengatur alokasi belanja di bidang kesehatan sebagai sesuatu yang mutlak dipenuhi (mandatory spending). Pasal tersebut menyebutkan bahwa pemerintah mengalokasikan anggaran kesehatan sebesar sekurang-kurangnya lima persen dari APBN, sementara pemerintah provinsi dan kabupaten/kota mengalokasikan anggaran kesehatan sekurang-kurangnya sepuluh persen dari APBD. Alokasi dana bidang pendidikan dan bidang kesehatan sebagaimana yang diatur dalam peraturan tersebut seharusnya tidak termasuk alokasi pembayaran gaji aparatur sipil negara yang bekerja di bidang pendidikan dan bidang kesehatan.

Dalam banyak penelitian sebelumnya, dana pendidikan dan kesehatan berpengaruh positif dan signifikan terhadap pembentukan IPM di berbagai lokasi dan waktu penelitian. Walaupun demikian, terdapat juga penelitian dengan hasil temuan dimana anggaran pendidikan ternyata berpengaruh negatif terhadap pembentukan IPM. Winarti (2014) menenggarai bahwa pengaruh negatif anggaran pendidikan terhadap IPM disebabkan oleh alokasi anggaran pendidikan yang tidak dialokasikan semuanya untuk meningkatkan kualitas pendidikan, namun juga dialokasikan untuk lainnya seperti gaji pegawai dan biaya pendidikan lainnya. Dengan adanya belanja pendidikan yang tidak efektif, tekanan pada APBN maupun APBD semakin berat. Anggaran belanja publik baik anggaran negara maupun anggaran daerah sudah banyak memiliki belanja yang memiliki karakteristik belanja mengikat. Belanja mengikat ini adalah belanja yang bersifat mandatory spending, yang wajib dialokasikan pemerintah seperti belanja pegawai, belanja operasional, pembayaran utang dan bunga serta dana transfer ke daerah.

Hajibabaei dan Ahmadi (2104) menyatakan bahwa pada saat bagian belanja pemerintah dari PDB masih berjumlah lebih kecil dari aturan yang berlaku, maka IPM akan terus meningkat seiring dengan peningkatan belanja pemerintah. namun apabila bagian belanja pemerintah dari PDB sudah lebih besar daripada aturan, maka IPM akan mengalami penurunan. Scully (2001) dalam penelitiannya menyatakan bahwa ada kondisi dimana belanja pemerintah sudah melampaui batas maksimal yang diperlukan untuk meningkatkan kualitas kehidupan (kesejahteraan masyarakat) maka pemerintah dapat mempertimbangkan untuk mengurangi jumlah belanja pemerintah. Dalam kondisi tertentu, pengurangan jumlah alokasi anggaran belanja tidak akan menurunkan kesejahteraan masyarakat. Pemerintah seharusnya memperhatikan tingkat efektifitas belanja yang dilakukan untuk meningkatkan kualitas kesejahteraan masyarakat, bukan pada pada seberapa besar jumlah uang yang dibelanjakan.

Berdasarkan latar belakang dan rumusan masalah tersebut, penelitian ini mengemukakan pertanyaan yaitu pertama, bagaimana pengaruh belanja pemerintah pusat bidang pendidikan, belanja pemerintah pusat bidang kesehatan, belanja pemerintah daerah bidang pendidikan dan belanja pemerintah daerah bidang kesehatan terhadap pembentukan IPM di Indonesia? Kedua, berapakah jumlah maksimum (atau minimum) belanja pemerintah bidang pendidikan dan kesehatan yang diperlukan untuk meningkatkan kualitas kehidupan manusia di Indonesia?

Tujuan penelitian ini adalah untuk menganalisis bagaimana pengaruh belanja pemerintah pusat bidang pendidikan, belanja pemerintah pusat bidang kesehatan, belanja pemerintah daerah bidang pendidikan dan belanja pemerintah daerah bidang kesehatan terhadap pembentukan IPM di Indonesia dan untuk menghitung dan mengetahui berapakah batas maksimum (atau minimum) belanja pemerintah bidang pendidikan dan kesehatan yang diperlukan untuk meningkatkan kualitas kehidupan manusia di Indonesia.

Bukti empiris hasil penelitian ini diharapkan menjadi bahan pertimbangan dan evaluasi bagi pemerintah baik pusat dan daerah dalam merumuskan kebijakan pengalokasian anggaran belanja bidang pendidikan dan bidang kesehatan yang memberikan dampak positif dalam peningkatan kesejahteraan masyarakat. 


\section{KERANGKA TEORI DAN PENGEMBANGAN HIPOTESIS}

\subsection{Pengeluaran pemerintah}

Pengeluaran pemerintah sering juga disebut pengeluaran publik, karena merupakan pengeluaran untuk membiayai program pemerintah dalam menjalankan pelayanan publik. Peraturan Pemerintah RI nomor 96 tahun 2012 tentang Pelaksanaan UU No. 25 Tahun 2009 tentang Pelayanan Publik, memberikan definisi pelayanan publik sebagai kegiatan atau rangkaian kegiatan dalam rangka pemenuhan kebutuhan pelayanan sesuai dengan peraturan perundang-undangan bagi setiap warga negara dan penduduk atas barang, jasa, dan/atau pelayanan administratif yang disediakan oleh penyelenggara pelayanan publik. Dalam peraturan pemerintah tersebut juga menyatakan bahwa Pemerintah Indonesia memberikan tiga jenis pelayanan publik kepada masyarakat yaitu pelayanan barang publik, pelayanan jasa publik, dan pelayanan administratif.

Dalam menjalankan aktivitas pembangunan nasional dan pelayanan publik, pemerintah membutuhkan dana yang sangat besar. Pengeluaran pemerintah merupakan kombinasi produk yang dihasilkan untuk melakukan pelayanan kepada masyarakat, baik berupa pengadaan dan pemeliharaan barang publik, biaya pelaksanaan jasa publik, dan pelayanan administratif. Setiap aktivitas pemerintah yang tercermin dari pengeluaran pemerintah sebaiknya memiliki dampak positif dalam pembangunan daerah dan negara, pembangunan perekonomian, dan pembangunan manusia.

Alokasi dari pertumbuhan ekonomi untuk pembangunan manusia merupakan fungsi dari tiga hal, yaitu total pengeluaran sektor publik, berapa banyak yang dialihkan untuk sektor-sektor yang berhubungan dengan peningkatan pembangunan manusia dan bagaimana dana tersebut dialokasikan ke dalam sektor tersebut (Ramirez, 1998). Pengeluaran pemerintah untuk pembangunan manusia melalui penyediaan pelayanan dasar akan sangat memengaruhi kualitas human capital di masa yang akan datang. Pemerintah memiliki kewajiban untuk menjamin dan melindungi warganya dengan menyediakan pelayanan dasar guna memenuhi hak-hak penduduknya. Pelayanan dasar yang mencakup di dalamnya pelayanan publik seperti layanan di bidang pendidikan dan bidang kesehatan akan mempunyai pengaruh pada pembangunan manusia.

Pengeluaran pemerintah di bidang pendidikan merupakan pengeluaran pemerintah yang sangat mendasar dalam pembangunan manusia. Pendidikan merupakan bagian penting dalam pencapaian kapabilitas manusia, yang juga bersifat esensial bagi kehidupan masyarakat. Pendidikan mempunyai peranan penting dalam rangka meningkatkan kemampuan suatu negara dalam menyerap teknologi modern, khususnya negara berkembang seperti Indonesia. Selain itu, pendidikan juga memainkan peranan penting dalam mengembangkan kapasitas dalam rangka mewujudkan pertumbuhan dan pembangunan yang berkesinambungan (sustainable growth).

Pendidikan merupakan investasi yang akan selalu berdampak pada waktu yang akan datang. Pendidikan menjadi modal dasar dalam pertumbuhan ekonomi maupun pembangunan bangsa. Pemerintah harus menyediakan alokasi belanja pada sektor pendidikan yang akan digunakan untuk membangun saran dan prasarana pendidikan serta melakukan investasi dalam membentuk modal manusia (human capital). Modal manusia merupakan investasi produktif terhadap orang-orang; mencakup pengetahuan, keterampilan, kemampuan, dan gagasan (Todaro \& Smith, 2011). Hal ini merupakan komponen penting dalam rangka mendukung program pembangunan, terutama pembangunan ekonomi dengan skema benefit spillover. Besarnya pengeluaran pemerintah di sektor pendidikan akan menentukan seberapa besar pencapaian hasil pembangunannya.

Dalam konteks pembangunan ekonomi, kesehatan dan pendidikan mempunyai kaitan yang erat. Hal ini dapat digambarkan sebagaimana modal kesehatan yang semakin besar dapat meningkatkan pengembalian atas investasi di sektor pendidikan (Todaro \& Smith, 2011). Beberapa penelitian menujukkan bahwa orang-orang yang lebih sehat akan memperoleh upah yang lebih tinggi. Pengaruh kesehatan terhadap peningkatan penghasilan telah terbukti secara dalam beberapa penelitian yang dilakukan dengan menerapkan teknik statistik. Tingginya produktivitas para pekerja yang lebih sehat memungkinkan mereka untuk mendapatkan pekerjaan dengan upah yang lebih baik (Todaro \& Smith, 2011).

Investasi pemerintah di bidang kesehatan dapat berupa alokasi anggaran untuk membiayai pengadaan dan pemeliharaan sarana fisik dan nonfisik untuk di bidang kesehatan. Pemerintah membangun sarana dan prasarana publik sehingga masyarakat mendapatkan kemudahan akses terhadap pelayanan di sektor kesehatan. Dengan kemudahan masyarakat mendapat akses terhadap layanan kesehatan, maka kebutuhan dasar masyarakat akan kesehatan dapat dipenuhi sehingga kualitas kehidupan masyarakat menjadi meningkat. Dengan mengoptimalkan pengeluaran pemerintah, dalam hal ini khususnya pengeluaran untuk kepentingan kesehatan, maka kualitas kesehatan yang lebih baik dapat dihasilkan sehingga produktivitas yang tinggi akan lebih mudah dicapai. 


\subsection{Pembangunan Manusia}

Pembangunan manusia adalah salah satu indikator kemajuan suatu negara. Suatu negara dapat dikatakan maju bukan hanya dihitung dari Produk Domestik Bruto (PDB) saja, tetapi mencakup beberapa aspek yaitu aspek kesehatan dan pendidikan warga negaranya. Paradigma pembangunan terus mengalami perubahan evolusi, hingga saat ini paradigma pembangunan menjadikan manusia sebagai tujuan pembangunan. Kesadaran bahwa sumber daya manusia merupakan modal dasar dari kekayaan bangsa, sementara modal fisik dan sumber daya alam hanyalah faktor produksi yang bersifat pasif. Pada hakekatnya, manusialah yang akan berperan aktif dalam aktivitas kegiatan mengumpulkan modal, mengeksploitasi sumber daya alam dan melaksanakan pembangunan nasional.

Pada tahun 1990 United Nations Development Programme (UNDP) dalam laporannya "Global Human Development Report" memperkenalkan konsep pembangunan manusia sebagai paradigma baru dalam model pembangunan. Menurut UNDP (1990) pembangunan manusia dirumuskan sebagai perluasan pilihan bagi penduduk, yang dapat dilihat sebagai proses upaya ke arah perluasan pilihan dan sekaligus sebagai taraf yang dicapai dari upaya tersebut. Pada saat yang sama, pembangunan manusia dapat dilihat juga sebagai pembangunan kemampuan manusia melalui perbaikan taraf kesehatan, pengetahuan, dan keterampilan sekaligus sebagai pemanfaatan kemampuan atau keterampilan yang dimiliki. Konsep pembangunan tersebut lebih luas pengertiannya apabila dibandingkan dengan konsep pembangunan ekonomi yang menekankan pada pertumbuhan, kebutuhan dasar, kesejahteraan masyarakat, atau pengembangan sumber daya manusia.

Definisi pembangunan manusia menurut UNDP tersebut pada dasarnya mencakup dimensi pembangunan yang sangat luas. Dalam konsep pembangunan manusia, pembangunan seharusnya dianalisis serta dipahami dari sudut manusianya, bukan hanya dari pertumbuhan ekonominya. Dari definisi UNDP tersebut mencerminkan bahwa manusia dalam suatu wilayah selayaknya memiliki dan diberikan pilihan-pilihan yang luas dan dibutuhkan dukungan dari pemerintah guna memberikan sarana bagi masyarakat untuk dapat memanfaatkan dan mengambil keputusan sesuai dengan pilihan yang diambilnya. Dalam hal ini pemerintah merupakan fasilitator bagi masyarakat untuk mendapatkan pilihan-pilihan yang lebih luas. Gambaran yang dapat diambil guna melihat seberapa jauh peran pemerintah untuk menjadi fasilitator dari pembangunan manusia adalah melalui kebijakasanaan pengeluaran pemerintah. Salah satu hal yang paling menentukan dalam suksesnya pembangunan manusia adalah pengeluaran pemerintah di sektor pendidikan dan sektor kesehatan, sehingga dua sektor tersebut menjadi prioritas bagi pemerintah untuk mewujudkan pembangunan manusia yang pada akhirnya menjadi input dalam proses pembangunan di berbagai sektor.

Menurut Todaro dan Smith (2015), sumber daya manusia merupakan faktor yang paling menentukan karakter dan kecepatan dalam proses pembangunan suatu negara, sumber daya manusia merupakan modal dasar dari kekayaan suatu bangsa. Modal fisik dan sumber daya alam hanyalah faktor produksi yang bersifat pasif, manusialah yang merupakan agen aktif yang akan mengumpulkan modal, mengeksploitasi sumber daya alam dan melaksanakan pembangunan nasional.

UNDP (United Nation Development Programme) mendefinisikan pembangunan manusia sebagai suatu proses untuk memperluas pilihan-pilihan bagi penduduk. Dalam konsep tersebut penduduk ditempatkan sebagai tujuan akhir (the ultimate end), sedangkan upaya pembangunan dipandang sebagai sarana (principal means) untuk mencapai tujuan tersebut. Untuk menjamin tercapainya tujuan pembangunan manusia terdapat empat hal yang harus diperhatikan yaitu produktivitas, pemerataan, kesinambungan dan pemberdayaan (UNDP, 1990)

Pengukuran pembangunan manusia pertama kali diperkenalkan oleh UNDP pada tahun 1990. UNDP memperkenalkan sebuah gagasan baru dalam pengukuran pembangunan manusia yang disebut sebagai Indeks Pembangunan Manusia (IPM). Sejak saat itu, IPM dipublikasikan secara berkala dalam laporan tahunan Human Development Report (HDR). IPM menjelaskan bagaimana penduduk dapat mengakses hasil pembangunan dalam memperoleh pendapatan, kesehatan, pendidikan, dan sebagainya. Menurut UNDP, Indeks Pembangunan Manusia (IPM) mengukur capaian pembangunan manusia berbasis sejumlah komponen dasar kualitas hidup. Sebagai ukuran kualitas hidup, IPM dibangun melalui pendekatan tiga dimensi dasar. Dimensi tersebut mencakup: umur panjang dan hidup sehat (a long and healthy life); pengetahuan (knowledge); dan standar hidup layak (decent standard of living). Ketiga dimensi tersebut memiliki pengertian sangat luas karena terkait banyak faktor. IPM harus dilihat sebagi penyederhanaan dari realitas yang kompleks dari luasnya dimensi pembangunan manusia, karena hanya mencakup tiga dimensi dasar kualitas hidup manusia.

Indeks Pembangunan Manusia (IPM) menjadi salah satu indikator yang penting dalam melihat sisi lain dari pembangunan. IPM memiliki manfaat penting antara lain menjadi indikator penting untuk mengukur keberhasilan dalam upaya membangun 
kualitas hidup manusia (masyarakat/penduduk) dan dapat menentukan peringkat atau level pembangunan suatu wilayah/negara. Bagi Indonesia, IPM merupakan data strategis karena selain sebagai ukuran kinerja Pemerintah, IPM juga digunakan sebagai salah satu faktor yang menjadi penentu besarnya alokasi Dana Alokasi Umum (DAU) (BPS, 2015).

Menurut UNDP dalam BPS (2015), indeks pembangunan manusia mengukur capaian pembangunan manusia berbasis sejumlah komponen dasar kualitas hidup. Sebagai ukuran kualitas hidup, IPM dibangun melalui pendekatan tiga dimensi dasar. Dimensi tersebut mencakup umur panjang dan sehat, pengetahuan, dan kehidupan yang layak. Ketiga dimensi tersebut memiliki pengertian sangat luas karena terkait banyak faktor. Untuk mengukur dimensi kesehatan, digunakan angka harapan hidup waktu lahir. Selanjutnya, untuk mengukur dimensi pengetahuan digunakan gabungan indikator harapan lama sekolah dan rata-rata lama sekolah. Adapun untuk mengukur dimensi hidup layak digunakan indikator kemampuan daya beli (purchasing power parity). Kemampuan daya beli masyarakat terhadap sejumlah kebutuhan pokok yang dilihat dari ratarata besarnya pengeluaran per kapita sebagai pendekatan pendapatan yang mewakili capaian pembangunan untuk hidup layak.

Capaian pembangunan manusia di suatu wilayah pada waktu tertentu dapat dikelompokan ke dalam empat kelompok. Pengelompokan ini bertujuan untuk mengorganisasikan wilayahwilayah menjadi kelompok-kelompok yang sama dalam hal pembangunan manusia. Kategori pengelompokan capaian pembangunan manusia yaitu IPM yang bernilai kurang dari 60 masuk kedalam kategori IPM rendah, daerah yang memiliki nilai IPM berada di antara 60 dan 70 masuk ke dalam kategori IPM sedang, untuk daerah yang memiliki nilai IPM di antara 70 dan 80 masuk ke dalam kategori IPM tinggi, dan untuk daerah yang memiliki nilai IPM lebih dari 80 berada di kategori IPM sangat tinggi.

\subsection{Penelitian Terdahulu}

Berbagai penelitian terdahulu yang telah dilakukan, menunjukkan bahwa belanja pemerintah bidang pendidikan dan bidang kesehatan memiliki pengaruh yang signifikan terhadap pembentukan IPM. Hal ini bias ditemukan pada penelitian yang dilakukan oleh Gupta, Clements dan Tiongson (1998), Tomas (2011), Fattah dan Muji (2012), Razmi (2012), Setyowati dan Suparwati (2012), Astri, Nikensari dan Kuncara (2013), Iheoma (2014), Arifin, Suswandi dan Adenan (2015), dan pada peneitian Heka, Lapian dan Lajuck (2017). Walau demikian, terdapat beberapa penelitian dimana belanja pemerintah bidang pendidikan dan/atau kesehatan tidak memberikan pengaruh signifikan terhadap pembentukan IPM. Hal ini dapat dilihat pada penelitian Badrudin dan Khasanah (2011), Vegirawati (2012), Kahang, Saleh dan Suharto (2016), serta Zulham dan Seftarita (2017).

Selain itu, terdapat hal yang menarik dari beberapa penelitian antara lain penelitian dari Scully (2001) dimana pengeluaran konsumsi pemerintah berada pada kondisi lebih besar dari jumlah yang diperlukan untuk memaksimumkan kualitas kehidupan, penelitian Prasetyo dan Zuhdi (2013) mengemukakan bahwa pemerintah perlu melakukan efisiensi dalam melaksanakan belanja pemerintah untuk mencapai pembentukan IPM yang lebih baik, dan pada penelitian Hajibabaei dan Ahmadi (2014) dimana bagian pengeluaran pemerintah dalam PDB memiliki nilai maksimum untuk dapat meningkatkan IPM, jika nilai maksimum itu terlampaui, maka justru akan mengurangi IPM.

\section{METODOLOGI PENELITIAN}

Sesuai dengan permasalahan dan tujuan yang diambil dalam penelitian ini, maka penelitian ini menggunakan pendekatan kuantitatif. Penelitian ini mengambil populasi seluruh daerah yang ada di Indonesia. Dalam penelitian ini, jumlah provinsi yang dijadikan objek penelitian yakni sebesar 32 provinsi. Terdapat dua provinsi yang tidak dimasukan dalam objek penelitian, yaitu provinsi DKI Jakarta dan Provinsi Kalimantan Utara. Provinsi DKI Jakarta tidak dimasukan dalam objek penelitian karena belanja pemerintah pusat yang berlokasi di Provinsi DKI Jakarta, merupakan gabungan antara belanja yang dilakukan dari tingkat kementerian dan tingkat provinsi. Hal ini menyebabkan data Provinsi DKI Jakarta bersifat outlier jika dibandingkan dengan data dari provinsi lainnya. Provinsi Kalimantan Utara tidak dimasukan dalam objek penelitian karena merupakan provinsi baru sehingga data yang tersedia masih terbatas. Jangka waktu penelitian dan data yang digunakan mulai tahun 2010 sampai dengan tahun 2016.

Variabel dependen yang digunakan dalam penelitian ini yakni IPM, dan variabel independen antara lain persentase belanja pemerintah pusat bidang pendidikan dari PDRB, persentase belanja pemerintah pusat bidang kesehatan dari PDRB, persentase belanja pemerintah daerah bidang pendidikan dari PDRB, dan persentase belanja pemerintah daerah bidang kesehatan dari PDRB, serta menggunakan persentase belanja pemerintah pusat bidang infrastruktur dari PDRB persentase belanja pemerintah daerah bidang infrastruktur dari PDRB sebagai variabel kontrol.

Penelitian ini memisahkan belanja pemerintah ke dalam tiga kategori yaitu belanja pemerintah bidang pendidikan, belanja pemerintah bidang kesehatan dan belanja pemerintah bidang infrastruktur. Hal ini disebabkan karena tiga 
kategori belanja pemerintah ini yang secara langsung bertujuan untuk meningkatkan kualitas kehidupan masyarakat. IPM sebagai indeks komposit yang mengukur kualitas kehidupan masyarakat dibentuk dari tiga indikator yaitu indikator pendidikan, kesehatan dan pengeluaran.

Dalam penelitian ini, definisi operasional variabel adalah sebagai berikut.

1. Indeks Pembangunan Manusia (IPM) adalah angka indeks pembangunan manusia berdasarkan hasil penghitungan dari Badan Pusat Statistik Indonesia. Penggunaan Indeks pembangunan manusia diasumsikan sebagai indeks komposit tunggal yang diukur dalam satuan angka.

2. Persentase belanja pemerintah pusat bidang pendidikan dari PDRB adalah jumlah total belanja bidang pendidikan yang berasal dari APBN dibagi dengan angka PDRB riil tahun dasar 2010 pada masing-masing provinsi. Variabel ini diukur dalam satuan persen.

3. Persentase belanja pemerintah pusat bidang kesehatan dari PDRB adalah jumlah total belanja bidang kesehatan yang berasal dari APBN dibagi dengan angka PDRB ril tahun dasar 2010 pada masing-masing provinsi. Variabel ini diukur dalam satuan persen.

4. Persentase belanja pemerintah daerah bidang pendidikan dari PDRB, adalah jumlah total belanja bidang pendidikan yang berasal dari APBD dibagi dengan angka PDRB riil tahun dasar 2010 pada masing-masing provinsi. Variabel ini diukur dalam satuan persen.

5. Persentase belanja pemerintah daerah bidang kesehatan dari PDRB adalah jumlah total belanja bidang kesehatan yang berasal dari APBD dibagi dengan angka PDRB riil tahun dasar 2010 pada masing-masing provinsi. Variabel ini diukur dalam satuan persen.

6. Persentase belanja pemerintah pusat bidang infrastruktur dari PDRB adalah jumlah total belanja bidang perumahan dan fasilitas umum yang berasal dari APBN dibagi dengan angka PDRB riil tahun dasar 2010 pada masingmasing provinsi. Variabel ini diukur dalam satuan persen.

7. Persentase belanja pemerintah daerah bidang infrastruktur dari PDRB adalah jumlah total belanja bidang perumahan dan fasilitas umum yang berasal dari APBD dibagi dengan angka PDRB riil tahun dasar 2010 pada masingmasing provinsi. Variabel ini diukur dalam satuan persen.

Model penelitian ini akan menggunakan metode analisis data panel dengan pendekatan regresi kuadratik. Penggunaan metode analisis regresi kuadratik bertujuan untuk memperoleh titik optimal variabel independen untuk memperoleh nilai variabel dependen yang maksimal. Persamaan regresi untuk melihat pengaruh belanja pemerintah bidang pendidikan dan kesehatan terhadap IPM dalam penelitian ini adalah:

$$
\begin{aligned}
& I P M_{i t}=\alpha_{0}+\beta_{1} D I K_{-} P_{i t}+\beta_{2} D I K_{-} D_{i t}+ \\
& \beta_{3} S H T_{-} P_{i t}+\beta_{4} S H T_{-} D_{i t}+\beta_{5} D I K_{-} P_{i t}{ }^{2}+ \\
& \beta_{6} D I K_{-} P_{i t}{ }^{2}+\beta_{7} D I K_{-} P_{i t}{ }^{2}+\beta_{8} D I K_{-} P_{i t}{ }^{2}+ \\
& \beta_{9} I N F_{-} P_{-} i t+\beta_{10} I N F_{-} D_{-} i t+\mu_{i t} \text { (3.2) } \\
& \text { di mana: } \\
& \text { IPM = Indeks Pembangunan Manusia } \\
& \alpha 0=\text { Konstanta } \\
& \beta 1-\beta 8=\text { Koefisien Variabel hasil regresi } \\
& \text { terhadap IPM } \\
& \beta 9 \text { dan } \beta 10=\text { Koefisien Variabel Kontrol } \\
& \text { DIK_P } \quad=\text { Persentase belanja pemerintah } \\
& \text { pusat bidang pendidikan dari PDRB } \\
& \text { DIK_D = Persentase belanja pemerintah }
\end{aligned}
$$
INF_P $\quad=$ Persentase belanja pemerintah pusat bidang fasilitas umum dari PDRB

\section{HASIL PENELITIAN}

Setelah dilakukan uji terhadap model, maka penelitian ini lebih tepat menggunakan metode Random Effect Model dari analisis regresi data panel. Berdasarkan hasil estimasi dengan Random Effect Model (REM) yang telah dilakukan, persamaan regresi data panel adalah: 


$$
\begin{aligned}
\widehat{I P M}=66,68- & 0,57 D I K_{-} P_{i t}+0,63 D I K_{-} D_{i t} \\
& +4,34 S H T_{-} P_{i t}-1,43 S H T_{-} D_{i t} \\
& +0,007 D I K_{-} P 2_{i t} \\
& -0,25 D I K_{-} D 2_{i t}-2,67 S H T_{-} P 2_{i t} \\
& -0,05 S H T_{-} D 2_{i t}+1,45 I N F_{-} P_{i t} \\
& +0,12 I N F_{-} D_{i t}
\end{aligned}
$$

Uji $t$ untuk melihat signifikansi secara individual pengaruh independent variable terhadap dependent variable sebagai berikut.

1. Persentase belanja pemerintah pusat bidang pendidikan dari PDRB (DIK_P) tidak berpengaruh secara signifikan terhadap IPM baik $\alpha=1 \%, \alpha=5 \%$ maupun $\alpha=10 \%$.

2. Persentase belanja pemerintah pusat bidang kesehatan dari PDRB (SHT_P) berpengaruh positif dan signifikan terhadap IPM pada $\alpha=1 \%$.

3. Persentase belanja pemerintah daerah bidang pendidikan dari PDRB (DIK_D) berpengaruh positif dan signifikan terhadap IPM pada $\alpha=5 \%$.

4. Persentase belanja pemerintah daerah bidang kesehatan dari PDRB (SHT_D) berpengaruh negatif dan signifikan terhadap IPM pada $\alpha=1 \%$.

5. Persentase belanja pemerintah pusat bidang infrastruktur dari PDRB (INF_P) bepengaruh secara positif dan signifikan terhadap IPM pada $\alpha=1 \%$.

6. Persentase belanja pemerintah pusat bidang infrastruktur dari PDRB (INF_D) tidak berpengaruh secara signifikan terhadap IPM pada $\alpha=1 \%, \alpha=5 \%$ maupun $\alpha=10 \%$

7. Persentase belanja pemerintah pusat bidang pendidikan dari PDRB kuadrat (DIK_P2) tidak berpengaruh secara signifikan terhadap IPM baik $\alpha=1 \%, \alpha=5 \%$ maupun $\alpha=10 \%$.

8. Persentase belanja pemerintah pusat bidang kesehatan dari PDRB kuadrat (SHT_P2) tidak berpengaruh secara signifikan terhadap IPM baik $\alpha=1 \%, \alpha=5 \%$ maupun $\alpha=10 \%$.

9. Persentase belanja pemerintah daerah bidang pendidikan dari PDRB kuadrat (DIK_D2) tidak berpengaruh secara signifikan terhadap IPM baik $\alpha=1 \%, \alpha=5 \%$ maupun $\alpha=10 \%$.

10. Persentase belanja pemerintah daerah bidang kesehatan dari PDRB kuadrat (SHT_D2) tidak berpengaruh secara signifikan terhadap IPM baik $\alpha=1 \%, \alpha=5 \%$ maupun $\alpha=10 \%$.

Selanjutnya dilakukan uji $\mathrm{F}$ atau uji serentak untuk mengetahui apakah semua independent variable secara bersama-sama berpengaruh signifikan terhadap dependent variable. Berdasarkan Tabel 1 dapat dilihat nilai probability $\mathrm{F}$ sebesar 0,0000. Artinya, variabel persentase belanja pemerintah pusat bidang pendidikan dari PDRB, persentase belanja pemerintah pusat bidang kesehatan dari PDRB, persentase belanja pemerintah daerah bidang pendidikan dari PDRB, dan persentase belanja pemerintah daerah bidang kesehatan dari PDRB, serta persentase belanja pemerintah pusat bidang infrastruktur dari PDRB dan persentase belanja pemerintah pusat bidang infrastruktur dari PDRB secara bersama-sama berpengaruh signifikan terhadap pembentukan IPM pada $\alpha=1 \%$.

Kemudian selanjutnya adalah uji koefisien determinasi (R2), yaitu untuk mengetahui seberapa besar proporsi variasi dari dependent variable yang dijelaskan oleh semua independent variable. Berdasarkan Tabel 6, dapat dilihat nilai koefisien determinasi sebesar 0,2283. Artinya, variasi pembentukan IPM dapat dijelaskan oleh model sebesar 22,83\% dan sisanya sebesar $77,17 \%$ dijelaskan oleh variabel lain di luar model.

Interpretasi dari persamaan regresi data panel dengan metode random effect model pada penelitian ini adalah sebagai berikut.

1. Nilai konstanta sebesar 66,51 diinterpretasikan sebagai taksiran besaran nilai IPM yang tidak dipengaruhi oleh persentase belanja pemerintah pusat bidang pendidikan dari PDRB, persentase belanja pemerintah pusat bidang kesehatan dari PDRB, persentase belanja pemerintah daerah bidang pendidikan dari PDRB, dan persentase belanja pemerintah daerah bidang kesehatan dari PDRB, serta persentase belanja pemerintah pusat bidang infrastruktur dari PDRB dan persentase belanja pemerintah pusat bidang infrastruktur dari PDRB.

2. Koefisien DIK_P tidak berpengaruh signifikan terhadap IPM

3. Nilai koefisien DIK_D sebesar 0,63 menunjukkan setiap kenaikan persentase belanja pemerintah daerah bidang pendidikan dari PDRB sebesar 1\%, maka akan meningkatkan nilai IPM sebesar 0,63 poin indeks, ceteris paribus. Alokasi anggaran pengeluaran pemerintah terhadap pendidikan merupakan wujud nyata dari investasi untuk meningkatkan produktivitas masyarakat. Investasi pendidikan merupakan sarana untuk meningkatkan pembangunan manusia sehingga tujuan untuk meningkatkan kesejahteraan dapat tercapai.

4. Nilai koefisien SHT_P sebesar 4,34 menunjukkan setiap kenaikan persentase belanja pemerintah pusat bidang kesehatan dari PDRB sebesar 1\%, akan meningkatkan nilai IPM sebesar 4,34 poin indeks, ceteris paribus. Investasi yang tepat di bidang kesehatan akan memberikan dampak positif terhadap pembangunan manusia. Penggunaan alokasi untuk pembangunan gedung kesehatan seperti rumah sakit dan puskesmas, serta pengadaan obat dan alat-alat kesehatan dapat meningkatkan kualitas kesehatan yang dimiliki oleh masyarakat. Peningkatan kepedulian masyarakat tentang 
cara hidup sehat juga memberikan dampak positif terhadap peningkatan taraf kesehatan masyarakat.

5. Nilai koefisien SHT_D sebesar 1,43 menunjukkan setiap kenaikan persentase belanja pemerintah daerah bidang kesehatan dari PDRB sebesar 1\%, maka akan menurunkan nilai IPM sebesar 1,43 poin indeks, ceteris paribus. Sanggelorang, Rumate dan Siwu (2015) mengemukakan bahwa belanja pemerintah bidang kesehatan berpengaruh negatif karena alokasi anggaran yang ada masih lebih besar digunakan untuk pengadaan sarana dan prasarana kesehatan seperti pembangunan rumah sakit dan puskesmas. Zulham dan Seftarita (2015) juga mengemukakan bahwa alokasi belanja kesehatan belum tepat sasaran untuk dapat berpengaruh positif terhadap IPM. Hal ini disebabkan karena sebagian besar anggaran masih bertumpu pada belanja kuratif (penyembuhan) dari pada preventif (pencegahan). Terdapat 3 program prioritas pemerintah daerah di Indonesia yang dijalankan, yaitu: peningkatan jumlah dan kualitas sarana dan prasarana layanan kesehatan, pembebasan biaya layanan kesehatan dan peningkatan kesehatan ibu dan anak. Anggaran kesehatan dari APBD pemerintah daerah antara lain digunakan untuk bantuan iuran kesehatan masyarakat tidak mampu, pembangunan baru, peningkatan dan pemeliharaan sarana prasarana kesehatan (seperti rumah sakit, puskesmas), jaminan kesehatan daerah. Di samping itu, dialokasikan juga anggaran kesehatan pada DAK Fisik Bidang Kesehatan dengan output antara lain pengadaan kendaraan farmasi, kendaraan ambulans, pembangunan gedung kantor, pengadaan sarpras kesehatan, pembangunan puskesmas kelililing, pengolahan air limbah, pengadaan alat-alat kesehatan, pengadaan obat-obatan, sepeda motor, pembangunan Balai Penyuluh KB dan sebagainya (Kanwil DJPb, 2018).

\section{KESIMPULAN DAN SARAN}

Berdasarkan hasil estimasi dan analisis mengenai pengaruh persentase belanja pemerintah pusat bidang pendidikan dari PDRB, persentase belanja pemerintah pusat bidang kesehatan dari PDRB, persentase belanja pemerintah daerah bidang pendidikan dari PDRB, dan persentase belanja pemerintah daerah bidang kesehatan dari PDRB terhadap pembentukan IPM di Indonesia selama periode tahun 2010 sampai dengan tahun 2016, maka diperoleh kesimpulan sebagai berikut.

Persentase belanja pemerintah pusat bidang pendidikan dari PDRB tidak berpengaruh secara signifikan terhadap IPM terhadap pertumbuhan IPM di Indonesia. Hal ini menunjukkan investasi di bidang pendidikan masih harus mendapat perhatian untuk mendapatkan pendanaan dari pemerintah khususnya dari alokasi belanja pemerintah pusat. Persentase belanja pemerintah pusat bidang kesehatan dari PDRB berpengaruh positif dan signifikan terhadap IPM di Indonesia. Hal ini menunjukkan investasi di bidang kesehatan khususnya dari alokasi belanja pemerintah pusat sudah tepat sasaran dan dalam pelaksanaan perlu terus menjaga dan meningkatkan kualitas pelayanan kesehatan terhadap masyarakat. Persentase belanja pemerintah daerah bidang pendidikan dari PDRB berpengaruh positif dan signifikan terhadap IPM di Indonesia. Hal ini menunjukkan belanja pemerintah daerah di bidang pendidikan pemerintah dapat membangun suatu sarana dan sistem pendidikan yang baik. Persentase belanja pemerintah daerah bidang kesehatan dari PDRB berpengaruh negatif dan signifikan terhadap IPM di Indonesia. Hal ini menunjukkan investasi di bidang kesehatan masih harus mendapat perhatian khususnya dari alokasi belanja pemerintah daerah. Alokasi belanja sebaiknya bertumpu pada belanja yang bersifat preventif (pencegahan) dari pada belanja kuratif (penyembuhan).

Untuk penghitungan jumlah maksimum (atau minimum) belanja pemerintah bidang pendidikan dan kesehatan yang diperlukan untuk meningkatkan kualitas kehidupan manusia di Indonesia pada penelitian ini tidak dapat ditentukan karena hasil regresi variabel-variabel kuadrat tidak berpengaruh signifikan terhadap IPM.

\section{IMPLIKASI DAN KETERBATASAN}

Berdasarkan hasil penelitian dan kesimpulan yang telah dipaparkan, maka implikasi yang dapat diberikan adalah agar pemerintah pusat dan daerah mampu mengoptimalkan dana untuk pendidikan dan kesehatan guna meningkatkan kualitas sumber daya manusia. Aturan mengenai alokasi minimum belanja pendidikan dan belanja kesehatan untuk APBN dan APBD merupakan suatu acuan yang baik, akan tetapi alokasinya harus tepat sasaran. Seberapa besar dana yang dialokasikan dalam penganggaran sebaiknya bukan didasarkan seberapa besar anggaran persentase anggaran tersebut dari total alokasi anggaran, namun sebaiknya mempertimbangkan bagaimana penggunaan dana tersebut dapat dilakukan dengan bijak dan tepat sasaran agar dapat memperbaiki kualitas sumber daya manusia.

Penelitian ini memiliki keterbatasan antara lain sebagai berikut.

1. Periode penelitian ini terbatas hanya 7 tahun sehingga memerlukan data dengan runtut waktu lebih lama lagi untuk memberikan gambaran pengaruh belanja pemerintah terhadap IPM yang lebih komprehensif 
2. Masih terdapat dua provinsi yang belum dimasukan dalam penelitian yaitu Provinsi DKI Jakarta dan Provinsi Kalimantan Utara disebabkan masalah ketersediaan data. Data cross-section yang lebih lengkap dapat memberikan gambaran pengaruh belanja pemerintah terhadap IPM yang lebih komprehensif.

3. Metode analisis yang digunakan dalam model ini kurang bisa menangkap gejala dampak pengeluaran pemerintah di bidang pendidikan dan kesehatan di masing-masing provinsi. Untuk melihat gejala di tiap provinsi, perlu dilakukan pengolahan data lebih detail dengan metode seperti Data Envelope Analysis, Stochastic Frontier Analysis, Input-Output Analysis, dan sebagainya.

\section{REFERENSI}

Anggraini, R. A., \& Muta'ali, L. Pola hubungan pertumbuhan ekonomi dan pembangunan manusia di Provinsi Jawa Timur tahun 20072011.

Arifin, M. Y., Suswandi, P. E., \& Adenan, M. (2015). Pengaruh pengeluaran pemerintah sektor kesehatan, pengeluaran pemerintah sektor pendidikan dan pertumbuhan ekonomi terhadap indeks pembangunan manusia Jawa Timur 2006-2013. Artikel Ilmiah Mahasiswa.

Astri, M., Nikensari, S. I., \& Kuncara, H. W. (2013). Pengaruh pengeluaran pemerintah daerah pada sektor pendidikan dan kesehatan terhadap indeks pembangunan manusia di Indonesia. Jurnal Pendidikan Ekonomi dan Bisnis, Vol. 1 (No. 1).

Badan Pusat Statistik. (2015). Indeks Pembangunan Manusia 2014 Metode Baru. Jakarta: Badan Pusat Statistik.

Badrudin, R., \& Khasanah, M. (2011). Pengaruh pendapatan dan belanja daerah terhadap pembangunan manusia di Provinsi Daerah Istimewa Yogyakarta. Buletin Ekonomi, Vol. 9 (No. 1), 1-82.

Baltagi, B. (2013). Econometric analysis of panel data (Fifth ed.). New Delhi: John Wiley and Sons Ltd.

Basuki, A. T. (2016). Econometric analysis of panel data. Jakarta: PT RAja Grafindo Perkasa.

Christy, F. A., \& Adi, P. H. (2009). Hubungan antara dana alokasi umum, belanja modal dan kualitas pembangunan manusia. The 3rd National Conference UKWMS. Surabaya.

Direktorat Penyusunan Anggaran. (2014). Pokokpokok siklus APBN di Indonesia. Jakarta.

Fattah, S., \& Muji, A. (2012). Local government expenditure allocation toward human development index at Jeneponto Regency, South Sulawesi, Indonesia. Journal of
Humanities and Social Science, Volume 5 (Issue 6), 40-50.

Gujarati, D. N., \& Porter, D. (2009). Basic economterics (Fifth ed.). New York: McGrawHill.

Gupta, S., Clements, B., \& Tjongson, E. (1998). Public spending on human development. Finance \& Development, Vol. 35 (No. 3).

Hajibabaei, H., \& Ahmadi, A. (2014). Government size and human development: quadratic regression approach. International Journal of Academic Research in Business and Social Science, Vol. 4 (No. 4).

Heka, A. J., Lapian, A., \& Lajuck, I. (2017). Pengaruh pengeluaran pemerintah bidang kesehatan dan pendidikan terhadap indeks pembangunan manusia di Provinsi Sulawesi Utara.

Iheoma, C. G. (2014). Impact of social spending on human development in Sub-Saharan Africa. American Journal of Social Sciences, Vol. 2 (No. 2), 29-35.

Kahang, M., Saleh, M., \& Suharto, B. (2016). Pengaruh pengeluaran pemerintah sektor pendidikan dan kesehatan terhadap indeks pembangunan manusia di Kabupaten Kutai Timur.

Kanwil DJPB Prov. Aceh. (2018). Kajian fiskal regional provinsi Aceh tahun 2017.

Kanwil DJPB Prov. Bali. (2018). Kajian fiskal regional provinsi Bali tahun 2017.

Kanwil DJPB Prov. Bangka Belitung. (2018). Kajian fiskal regional Provinsi Bangka Belitung tahun 2017.

Kanwil DJPB Prov. Banten. (2018). Kajian fiskal regional Provinsi Banten tahun 2017.

Kanwil DJPB Prov. Bengkulu. (2018). Kajian fiskal regional Provinsi Bengkulu tahun 2017.

Kanwil DJPB Prov. D.I. Yogyakarta. (2018). Kajian fiskal regional Provinsi D.I. Yogyakarta tahun 2017.

Kanwil DJPB Prov. Gorontalo. (2018). Kajian fiskal regional Provinsi Gorontalo tahun 2017.

Kanwil DJPB Prov. Jambi. (2018). Kajian fiskal regional Provinsi Jambi tahun 2017.

Kanwil DJPB Prov. Jawa Barat. (2018). Kajian fiskal regional Provinsi Jawa Barat tahun 2017.

Kanwil DJPB Prov. Jawa Tengah. (2018). Kajian fiskal regional Provinsi Jawa Tengah tahun 2017.

Kanwil DJPB Prov. Jawa Timur. (2018). Kajian fiskal regional Provinsi Jawa Timur tahun 2017.

Kanwil DJPB Prov. Kalimantan Barat. (2018). Kajian fiskal regional Provinsi Kalimantan Barat tahun 2017. 
Kanwil DJPB Prov. Kalimantan Tengah. (2018). kajian fiskal Regional Provinsi Kalimantan Tengah tahun 2017.

Kanwil DJPB Prov. Kalimantan Timur. (2018). Kajian fiskal regional Provinsi Kalimantan Timur tahun 2017.

Kanwil DJPB Prov. Kallimantan Selatan. (2018). Kajian fiskal regional Provinsi Kalimantan Selatan tahun 2017.

Kanwil DJPB Prov. Kepulauan Riau. (2018). Kajian fiskal regional Provinsi Kepulauan Riau tahun 2017.

Kanwil DJPB Prov. Lampung. (2018). Kajian fiskal regional Provinsi Lampung tahun 2017.

Kanwil DJPB Prov. Maluku. (2018). Kajian fiskal regional Provinsi Maluku tahun 2017.

Kanwil DJPB Prov. Maluku Utara. (2018). Kajian fiskal regional Provinsi Maluku Utara tahun 2017.

Kanwil DJPB Prov. Nusa Tenggara Barat. (2018). Kajian fiskal regional Provinsi Nusa Tenggara Barat tahun 2017.

Kanwil DJPB Prov. Nusa Tenggara Timur. (2018). Kajian fiskal regional Provinsi Nusa Tenggara Timur tahun 2017.

Kanwil DJPB Prov. Papua. (2018). Kajian fiskal regional Provinsi Papua tahun 2017.

Kanwil DJPB Prov. Papua Barat. (2018). Kajian fiskal regional Provinsi Papua Barat tahun 2017.

Kanwil DJPB Prov. Riau. (2018). Kajian fiskal regional Provinsi Riau tahun 2017.

Kanwil DJPB Prov. Sulawesi Barat. (2018). Kajian fiskal regional Provinsi Sulawesi Barat tahun 2017.

Kanwil DJPB Prov. Sulawesi Selatan. (2018). Kajian fiskal regional Provinsi Sulawesi Selatan tahun 2017.

Kanwil DJPB Prov. Sulawesi Tengah. (2018). Kajian fiskal regional Provinsi Sulawesi Tengah tahun 2017.

Kanwil DJPB Prov. Sulawesi Tenggara. (2018). Kajian fiskal regional Provinsi Sulawesi Tenggara tahun 2017.

Kanwil DJPB Prov. Sulawesi Utara. (2018). Kajian fiskal regional Provinsi Sulawesi Utara tahun 2017.

Kanwil DJPB Prov. Sumatera Barat. (2018). Kajian fiskal regional Provinsi Sumatera Barat tahun 2017.

Kanwil DJPB Prov. Sumatera Selatan. (2018). Kajian fiskal regional Provinsi Sumatera Selatan tahun 2017.

Kanwil DJPB Prov. Sumatera Utara. (2018). Kajian fiskal regional Provinsi Sumatera Utara tahun 2017.
Kanwil DJPB Prov. Sumatera Utara. (2018). Kajian fiskal regional Provinsi Sumatera Utara tahun 2018.

Kuncoro, M. (2010). Dasar-dasar ekonomika pembangunan (Edisi Kelima ed.). Yogyakarta: UPP STIM YKPN.

Latuconsina, Z. M. (2017). Analisis faktor-faktor yang mempengaruhi Indeks Pembangunan Manusia Kabupaten Malang berbasis pendekatan perwilayahan dan regresi panel. Journal of Regional and Rular Development Planning, 202-216.

Lyakurwa, W. M. (2007). Human capital and technoligy development: lessons for Africa. 2007 ADB annual meetings symposium. Shanghai, China.

Mangkoesoebroto, D. (2016). Ekonomi publik. Yogyakarta: BPFE-Yogyakarta.

Maqin, A. (2007). Indeks Pembangunan Manusia: tinjauan teoritis dan empiris di Jawa Barat. Pelatihan program pendanaan kompetisi Indeks Pembangunan Manusia. Kab. Sumedang.

Mardiasmo. (2009). Akuntansi sektor publik. Yogyakarta: ANDI.

Melliana, A., \& Zain, I. (2013). Analisis statistika faktor yang mempengaruhi Indeks Pembangunan Manusia di kabupaten/kota Provinsi Jawa Timur dengan menggunakan regresi panel. Jurnal Sains dan Seni Pomits, Vol. 2 (No. 2).

Nanga, M. (2000). Mencermati pergeseran dalam paradigma pembangunan. Meditek, Vol. 8 (No. 21).

Patemostro, S., Rajaram, A., \& Tjongson, E. R. (2005). How does the composition of public spending matter. World Bank Policy Research Working Paper 3555.

Peraturan Menteri Dalam Negeri 33 Tahun 2017 tentang Sinkronisasi Kebijakan Pemerintah Daerah dan Pemerintah Pusat. (2017).

Peraturan Menteri Dalam Negeri Nomor 86 Tahun 2017 tentang Tata Cara Perencanaan, Pengendalian dan Evaluasi Pembangunan Daerah, Tata Cara Evaluasi Rancangan Peraturan Daerah Tentang Rencana Pembangunan Jangka Panjang Daerah dan Rencana Pembangunan Jangka. (2017).

Peraturan Pemerintah Republik Indonesia Nomor 17 Tahun 2017 tentang Sinkronisasi Perencanaan dan Penganggaran Pembangunan Nasional. (2017).

Peraturan Pemerintah Republik Indonesia Nomor 96 Tahun 2012 tentang Pelaksanaan UndangUndang Nomor 25 Tahun 2009 tentang Pelayanan Publik. (2012). 
Prasetyo, A. D., \& Zuhdi, U. (2013). The government expenditure efficiency towards the human development. Procedia Economics and Finance, 615-622.

Rajkumar, A. S., \& Swaroop, V. (2008). Public apending and outcomes: does governance matter? Journal of Development Economics, 96111.

Ramirez, A., Ranis, G., \& Stewart, F. (1998). Economic growth and human development. QEH Working Paper Series.

Ranis, G., Stewart, F., \& Ramirez, A. (2000). Economic growth and human development. World Development, Vol. 28 (No. 2), 197-219.

Razmi, M. J. (2012). Investigating the effect of government health expenditure on HDI in Iran. Journal of Knowledge Management, Economics and Information Technology(Issue 5).

Reksoprayitno, S. (2000). Pengantar ekonomi makro (Edisi 6 ed.). Yogyakarta: BPFE Yogyakarta.

Ritonga, I. T. (2010). Perencanaan dan penganggaran keuangan daerah di Indonesia. Yogyakarta: Sekolah Pascasarjana UGM.

Ritonga, I. T. (2014). Analisis laporan keuangan pemerintah daerah. Yogyakarta: Pustaka Pelajar.

Safitri, I. (2016). Pengaruh pengeluaran pemerintah sektor kesehatan, pendidikan dan infrastruktur terhadap indeks pembangunan manusia di Provinsi Aceh. Jurnal Ilmiah Mahasiswa Ekonomi Pembangunan FEB Unsyiah, Volume 1 Nomor 1, Agustus 2016 Hal 66-76.

Sanggelorang, S. M., Rumate, V. A., \& Siwu, H. F. (2015). Pengaruh pengeluaran pemerintah di sektor pendidikan dan kesehatan terhadap Indeks Pembangunan Manusia di Sulawesi Utara. Jurnal Berkala Ilimah Efisiensi, Vol. 15(No. 02).

Scully, G. W. (2001). Government expenditure and quality of life. Public Choice, Vol. 108(No. 1/2), 123-145. Retrieved from www.jstor.org/stable/30026341

Setyowati, L., \& Suparwati, Y. K. (2012). Pengaruh pertumbuhan ekonomi, DAU, DAK, PAD Terhadap Indeks Pembangunan Manusia dengan pengalokasian anggaran belanja modal sebagai variabel intervening. Prestasi, Vol. 9 (No. 1).

Smyth, G. K. (2002). Nonlinear regression. (A. H. ElShaarawi, \& W. W. Piegorsech, Eds.) Encyclopedia of Environment, 1405-1411.

Subagiyo, H. (2006). Pengaruh alokasi belanja pembangunan sektor pendidikan, sektor kesehatan dan PDRB per kapita terhadap Indeks Pembangunan Manusia (studi kasus Kabupaten.Kota di Provinsi Lampung).
Subandoro, Y. K., \& Amir, H. (2017). Pengaruh korupsi terhadap peranan pengeluaran pemerintah dalam meningkatkan pembangunan manusia. Kajian Ekonomi Keuangan, Vol. 3(No. 3).

Tiebout, C. M. (1956). A pure theory of local expenditures. The Journal of Political Economy, Vol. 64(No. 5), 416-424. Retrieved July 28th, 2008, from www.jstor.org/stable/1826343

Todaro, M. P., \& Smith, S. C. (2011). Pembangunan ekonomi (Edisi Kesebelas ed.). Erlangga.

Tomas, V. (2011). National competitiveness and expenditure on education, research and development.

Undang-Undang Dasar Negara Republik Indonesia Tahun 1945.

Undang-Undang Nomor 1 Tahun 2004 tentang Perbendaharaan Negara.

Undang-Undang Nomor 15 Tahun 2004 tentang Pemeriksaan Pengelolaan dan Tanggung Jawab Keuangan Negara.

Undang-Undang Nomor 17 Tahun 2003 tentang Keuangan Negara.

Undang-Undang Nomor 20 Tahun 2003 tentang Sistem Pendidikan Nasional.

Undang-Undang Nomor 22 Tahun 1999 tentang Pemerintahan Daerah.

Undang-Undang Nomor 36 Tahun 2009 tentang Kesehatan.

UNDP. (1990). Human development report 1990. New York: Oxford University Press. 
Tabel 1 Statistik Deskrpitif Variabel Indeks Pembangunan Manusia

\begin{tabular}{|l|r|r|r|r|r|r|r|}
\hline \multicolumn{1}{|c|}{ Statistik Deskriptif } & \multicolumn{1}{c|}{$\mathbf{2 0 1 0}$} & \multicolumn{1}{c|}{$\mathbf{2 0 1 1}$} & \multicolumn{1}{c|}{$\mathbf{2 0 1 2}$} & \multicolumn{1}{c|}{$\mathbf{2 0 1 3}$} & \multicolumn{1}{c|}{$\mathbf{2 0 1 4}$} & \multicolumn{1}{c|}{$\mathbf{2 0 1 5}$} & \multicolumn{1}{c|}{$\mathbf{2 0 1 6}$} \\
\hline Mean & 65,25 & 65,85 & 66,46 & 67,12 & 67,64 & 68,25 & 68,83 \\
\hline Median & 65,68 & 66,26 & 66,84 & 67,55 & 68,11 & 68,82 & 69,44 \\
\hline Standard Deviation & 4,01 & 3,97 & 3,94 & 3,88 & 3,85 & 3,86 & 3,84 \\
\hline Range & 20,92 & 20,92 & 20,60 & 20,19 & 20,06 & 20,34 & 20,33 \\
\hline Minimum & 54,45 & 55,01 & 55,55 & 56,25 & 56,75 & 57,25 & 58,05 \\
\hline Maximum & 75,37 & 75,93 & 76,15 & 76,44 & 76,81 & 77,59 & 78,38 \\
\hline
\end{tabular}

Sumber: BPS (diolah), 2018

Tabel 2 Persentase belanja pemerintah pusat bidang pendidikan dari PDRB

\begin{tabular}{|l|c|c|c|c|c|c|c|}
\hline Statistik Deskriptif & $\mathbf{2 0 1 0}$ & $\mathbf{2 0 1 1}$ & $\mathbf{2 0 1 2}$ & $\mathbf{2 0 1 3}$ & $\mathbf{2 0 1 4}$ & $\mathbf{2 0 1 5}$ & $\mathbf{2 0 1 6}$ \\
\hline Mean & $1,17 \%$ & $1,81 \%$ & $1,82 \%$ & $1,59 \%$ & $1,66 \%$ & $1,74 \%$ & $1,58 \%$ \\
\hline Median & $0,99 \%$ & $1,40 \%$ & $1,41 \%$ & $1,27 \%$ & $1,35 \%$ & $1,57 \%$ & $1,32 \%$ \\
\hline Standard Deviation & $0,67 \%$ & $1,21 \%$ & $1,23 \%$ & $1,09 \%$ & $1,05 \%$ & $1,02 \%$ & $0,96 \%$ \\
\hline Range & $2,83 \%$ & $5,13 \%$ & $5,12 \%$ & $5,23 \%$ & $4,60 \%$ & $4,27 \%$ & $3,55 \%$ \\
\hline Minimum & $0,18 \%$ & $0,21 \%$ & $0,33 \%$ & $0,25 \%$ & $0,24 \%$ & $0,37 \%$ & $0,22 \%$ \\
\hline Maximum & $3,01 \%$ & $5,33 \%$ & $5,44 \%$ & $5,47 \%$ & $4,84 \%$ & $4,64 \%$ & $3,77 \%$ \\
\hline
\end{tabular}

Sumber: DJPb-Kemenkeu (diolah)

Tabel 3 Belanja pemerintah pusat bidang kesehatan riil per kapita

\begin{tabular}{|l|c|c|c|c|c|c|c|}
\hline Statistik Deskriptif & $\mathbf{2 0 1 0}$ & $\mathbf{2 0 1 1}$ & $\mathbf{2 0 1 2}$ & $\mathbf{2 0 1 3}$ & $\mathbf{2 0 1 4}$ & $\mathbf{2 0 1 5}$ & $\mathbf{2 0 1 6}$ \\
\hline Mean & $0,17 \%$ & $0,14 \%$ & $0,14 \%$ & $0,18 \%$ & $0,22 \%$ & $0,36 \%$ & $0,38 \%$ \\
\hline Median & $0,13 \%$ & $0,12 \%$ & $0,12 \%$ & $0,15 \%$ & $0,17 \%$ & $0,29 \%$ & $0,26 \%$ \\
\hline Standard Deviation & $0,13 \%$ & $0,11 \%$ & $0,09 \%$ & $0,14 \%$ & $0,20 \%$ & $0,25 \%$ & $0,34 \%$ \\
\hline Range & $0,47 \%$ & $0,43 \%$ & $0,36 \%$ & $0,65 \%$ & $0,84 \%$ & $0,97 \%$ & $1,34 \%$ \\
\hline Minimum & $0,01 \%$ & $0,01 \%$ & $0,02 \%$ & $0,02 \%$ & $0,03 \%$ & $0,03 \%$ & $0,04 \%$ \\
\hline Maximum & $0,48 \%$ & $0,45 \%$ & $0,38 \%$ & $0,67 \%$ & $0,86 \%$ & $1,01 \%$ & $1,38 \%$ \\
\hline
\end{tabular}

Sumber: DJPb-Kemenkeu (diolah)

Tabel 4 Belanja pemerintah daerah bidang pendidikan riil per kapita

\begin{tabular}{|l|c|c|c|c|c|c|c|}
\hline Statistik Deskriptif & $\mathbf{2 0 1 0}$ & $\mathbf{2 0 1 1}$ & $\mathbf{2 0 1 2}$ & $\mathbf{2 0 1 3}$ & $\mathbf{2 0 1 4}$ & $\mathbf{2 0 1 5}$ & $\mathbf{2 0 1 6}$ \\
\hline Mean & $2,90 \%$ & $3,67 \%$ & $3,84 \%$ & $4,10 \%$ & $3,81 \%$ & $3,75 \%$ & $3,09 \%$ \\
\hline Median & $2,74 \%$ & $3,42 \%$ & $3,48 \%$ & $3,80 \%$ & $3,51 \%$ & $3,25 \%$ & $2,98 \%$ \\
\hline Standard Deviation & $1,29 \%$ & $1,77 \%$ & $1,83 \%$ & $1,95 \%$ & $1,61 \%$ & $2,05 \%$ & $1,53 \%$ \\
\hline Range & $5,18 \%$ & $7,46 \%$ & $7,28 \%$ & $8,13 \%$ & $5,67 \%$ & $8,75 \%$ & $6,25 \%$ \\
\hline Minimum & $0,99 \%$ & $1,18 \%$ & $1,31 \%$ & $1,55 \%$ & $1,53 \%$ & $0,94 \%$ & $0,73 \%$ \\
\hline Maximum & $6,17 \%$ & $8,64 \%$ & $8,60 \%$ & $9,68 \%$ & $7,20 \%$ & $9,68 \%$ & $6,99 \%$ \\
\hline
\end{tabular}

Sumber: DJPK-Kemenkeu (diolah) 
Tabel 5 Belanja bidang kesehatan pemerintah daerah riil per kapita

\begin{tabular}{|l|c|c|c|c|c|c|c|}
\hline Statistik Deskriptif & $\mathbf{2 0 1 0}$ & $\mathbf{2 0 1 1}$ & $\mathbf{2 0 1 2}$ & $\mathbf{2 0 1 3}$ & $\mathbf{2 0 1 4}$ & $\mathbf{2 0 1 5}$ & $\mathbf{2 0 1 6}$ \\
\hline Mean & $1,08 \%$ & $1,23 \%$ & $1,32 \%$ & $1,51 \%$ & $1,51 \%$ & $1,59 \%$ & $1,82 \%$ \\
\hline Median & $1,02 \%$ & $1,12 \%$ & $1,25 \%$ & $1,43 \%$ & $1,42 \%$ & $1,23 \%$ & $1,72 \%$ \\
\hline Standard Deviation & $0,55 \%$ & $0,64 \%$ & $0,63 \%$ & $0,74 \%$ & $0,70 \%$ & $0,92 \%$ & $1,06 \%$ \\
\hline Range & $1,90 \%$ & $2,45 \%$ & $2,18 \%$ & $2,63 \%$ & $2,63 \%$ & $3,47 \%$ & $3,91 \%$ \\
\hline Minimum & $0,29 \%$ & $0,29 \%$ & $0,41 \%$ & $0,48 \%$ & $0,55 \%$ & $0,29 \%$ & $0,33 \%$ \\
\hline Maximum & $2,19 \%$ & $2,75 \%$ & $2,59 \%$ & $3,11 \%$ & $3,18 \%$ & $3,75 \%$ & $4,24 \%$ \\
\hline
\end{tabular}

Sumber: DJPK-Kemenkeu (diolah)

Tabel 6 Hasil Regresi Data Panel Menggunakan Random Effect Model

\begin{tabular}{|c|c|c|c|c|}
\hline \hline Variabel & Koefisien & Std. Error & t-Statistic & Prob. \\
\hline \hline C & 66.68163 & 0.781029 & 85.37668 & 0.0000 \\
\hline DIK_P & -0.578533 & 0.427419 & -1.353551 & 0.1773 \\
\hline DIK_D & 0.634715 & 0.321488 & 1.974303 & 0.0496 \\
\hline DIK_P2 & 0.007560 & 0.079908 & 0.094613 & 0.9247 \\
\hline DIK_D2 & -0.253338 & 0.184305 & -1.374561 & 0.1707 \\
\hline SHT_P & 4.349590 & 1.616165 & 2.691304 & 0.0077 \\
\hline SHT_D & -1.437283 & 0.295926 & -4.856902 & 0.0000 \\
\hline SHT_P2 & -2.678447 & 1.814358 & -1.476250 & 0.1414 \\
\hline SHT_D2 & -0.053627 & 0.034652 & -1.547567 & 0.1232 \\
\hline INF_P & 1.456069 & 0.542402 & 2.684481 & 0.0078 \\
\hline INF_D & 0.128149 & 0.130822 & 0.979568 & 0.3284 \\
\hline \hline \multicolumn{7}{|c|}{ Weighted Statistic } \\
\hline R-squared & 0.228283 & F-statistic & 6.300777 \\
\hline Adjusted R-squared & 0.192052 & Prob(F-statistic) & 0.000000 \\
\hline
\end{tabular}

